\title{
Self-directed work teams in information services: an exploratory study
}

\author{
G.J.J. de Jager* \\ Department of Library Services, University of South Africa, P.O. Box 392, Pretoria, 0001 Republic of South Africa \\ djagegjj@alpha.unisa.ac.za
}

Adeline S.A. du Toit

Department of Information Studies, Rand Afrikaans University, P.O. Box 524, Auckland Park, 2006 Republic of South Africa asadt@info.rau.ac.za

Received July 1997; accepted August 1997

\begin{abstract}
Classical management in information services and self-directed work teams are compared. Managerial activities are discussed and the possibility of self-directed work teams assuming responsibility for these activities are discussed. Attention is given to the formation of self-directed work teams, the role of individuals in such teams, the need for effective leadership, job enrichment and multi-skilling.

'n Vergelyking word getref tussen die tradisionele wyse van bestuur in inligtingsdienste en selfgerigte werkspanne. Die verskillende aktiwiteite wat bestuurders verrig, en of selfgerigte werkspanne hierdie aktiwiteite kan oorneem, word bespreek. Aandag word gegee aan die indeling en samestelling van selfgerigte werkspanne, die rol van individue in spanne, die noodsaaklikheid van doeltreffende leierskap, werksverryking en veelsydigheid.
\end{abstract}

*To whom correspondence should be addressed.

Until recently, the hierarchical management style was commonplace in enterprises. A single task was divided between people, which led to increased costs and ineffectiveness, because it took longer to finish a specific task. Communication between different levels of employees was poor. Enterprises were structure driven, and the role and function of individuals were emphasized (Saunier \& Hawk 1994:24). This was also the case in information services. For example, in the Unisa information service, the cataloguing process was divided into descriptive cataloguing and subject cataloguing.

As people's aspirations for personal freedom have increased, employees also want more power. Since the 1960s the traditional management style has begun to change. It developed from quality circles (1970s), problem solving and process improving teams (1980s) to self-directed work teams in the 1990s (Making teams work ... 1993:9). There is a tendency to move away from traditional hierarchical management towards participative management.

\section{Problem statement}

The following questions are addressed in this article:

- Can self-directed work teams lead to the empowerment of employees in information services?

- How can this empowerment develop employees?

- Can self-directed work teams play a role in the development of employees' potential?

It has been said that there are too many people doing too little in information services. Alternatives, like outsourcing certain tasks, are constantly considered. This means that enterprises outside the information service take over certain tasks. Usually the cataloguing process is one of the first to be outsourced. Redundant employees are either transferred to other divisions or retrenched. It is recommended that less drastic alternatives be considered.

In this article, the assumption is made that restructuring (a change in organizational management) by implementing selfdirected work teams (thus participative management) could be considered as one alternative. It is also assumed that selfdirected work teams could lead to increased productivity as well as the empowerment and development of workers.

A self-directed work team is a relatively new concept in South Africa, but there is world-wide interest in this tendency, especially in the United States. Most of the current research shows that this concept must be considered as an alternative to existing management styles. The democratization of the working environment (empowerment of employees) is emphasized (Andrews \& Herschel 1996:87; Winning team plays 1995:12). Many reports on case studies in different enterprises exist, but research about self-directed work teams in information services is relatively scarce. Osif and Harwood (1995:121) give an overview of useful literature on this topic, mostly in general management and/or economic journals. The majority of researchers are cautiously optimistic about this new phenomenon. Self-directed work teams do not always mean improved services and greater job satisfaction, and there may sometimes be difficulties resulting from the team structure itself or the individuals within it. Individuals can feel a loss of identity within the team (real or imagined), where their individual efforts appear to be lost in the team tasks and priorities. The necessity to change management styles is advocated and self-directed work teams are promoted as a feasible option (Osif \& Harwood 1995:117). However, changes should not occur too rapidly and advice is given on possible problems and pitfalls (Hughes 1994:44-46; White 1995:41-42). 
It is necessary to determine to what extent employees could be empowered, in other words, where the boudaries should be drawn between the power of self-directed work teams and traditional management (command and control enterprises), because supervisors may become redundant in a team environment. Remuneration (individual versus team) and the role of co-ordinators or team leaders should also be clarified. Restructuring should not just be window dressing but should have concrete advantages for employees as well as the employer.

\section{Classical (traditional) management versus self- directed work teams}

Classical or mechanistic management is based on bureaucracy that a hierarchy should be maintained in enterprises (Euske \& Roberts 1987:43). This implies formal, vertical communication as well as a high degree of specialization in enterprises, where the role of employees and how tasks should be done are clearly defined, thus a passive enterprise.

That specialization is a common feature in information services has already been mentioned. This style of management emphasizes the nature of employees, because a specialist is needed for a certain task. Other useful attributes of a specific employee might be overlooked. This contradicts empowerment.

Organismic or neo-classical management, on the other hand, emphasizes an individual's contribution to a common task. The exchange of information and advice occurs through consultation, not through managers instructing employees. This leads to a more rapid adaptation to change, because of the possibility of external liaison and the fact that individual input is not limited.

The concept of self-directed work teams is derived from the organismic management style. Self-directed work teams are small groups of trained employees (from diverse task spheres) who accept responsibility for a specific task. Team members must act on instructions, plan and schedule work and solve problems. In this way they are responsible for the management of the team (Katz 1993:34; Van der Lingen 1993:6). Katz (1993:44) indicates that individual, functional hierarchical barriers are eradicated, thus enabling employees of different divisions to co-operate. Newly formed teams are not self-directed but will become just that in the course of time.

In this article, self-directed work teams are defined as groups of employees, brought together (according to specific criteria) into functional teams to take responsibility for their work without constant supervision. Hawkins (1989:11-12) identifies six differences between classical management and self-directed workteams. Classical management entails that managers control employees by initiating decision making. In self-directed work teams, employees share responsibility and make their own decisions. This reflects democratic management as opposed to the traditional autocratic style (Curtis, Floyd \& Winsor 1992:33).
Power and decision making are shared in self-directed work teams. Leadership is therefore transferred from managers to employees (Van der Lingen 1993:7). In Successful team building ... (1992:159-160) it is stated that success is only possible if power and responsibility exist.

Classical management focusses on task maintenance whereas self-directed work teams focus on the social nature of the team. Task maintenance is still important but not above interpersonal relations. Management (and team leaders) should guard against any negativity. Human relations are just as important as doing the work (Euske \& Roberts 1987:13). Dividing tasks, such as the processing of books in the Unisa information service, leads to duplication and has an impact on timeliness. Self-directed work teams take control of a task in its entirety. Thus, specialization is avoided and it gives employees the opportunity to obtain more knowledge and experience.

The hierarchical structure of the classical management style implies vertical, downward communication, usually in the form of management's written instructions to employees. In self-directed work teams there are horizontal as well as vertical communication in the form of consultation between team members, and with other teams and enterprises. Facilitation rather than control is the keyword (Hawkins 1989:12). Classical management leads to programmed decision making, because of set rules. In self-directed work teams, though, creative decision making is possible because each team member's view is important and there is continuous contact with other colleagues and enterprises.

\section{Managerial activities in self-directed work teams}

It is important to determine the managerial activities that can be assumed by teams, in other words, just how much responsibility and control would be given to teams.

Van Lingen (1993:7) speaks of the transfer of power. Managers' responsibility for quality and quantity service is transferred to the teams. To determine the extent of the transferred responsibility, the managerial activities must be examined. Yukl (1989:62-65) indicates these activities according to Mintzberg's model of managerial roles. Mintzberg distinguishes three roles for managers and each of these is subdivided.

The interpersonal role involves interpersonal relations. As figurehead the manager symbolically displays power by the signing of documents, attending meetings, et cetera. $\mathrm{He} / \mathrm{she}$ also has the responsibility of supervision concerning appointing, dismissing, promoting and motivating of employees.

Team members, especially co-ordinators, can participate in supervision. According to Van Lingen (1993:7), it is possible for teams to be responsible for appointments and dismissals. White (1995:2), however, feels that managers should retain this responsibility. Present supervisors have reason to feel threatened, because they are usually appointed because of technical expertise. They could however be reappointed as team leaders or serve on steering committees (Hughes 1994: 
46). The manager's role of liaison (especially externally through conferences) could be assumed by teams.

Managers are also information processors. As monitors they must always be on the look out for information that could be used to the advantage of the enterprise. This information can be attained by liaison with the external environment as well as the media. In this capacity, they are the representatives of the enterprise. Employees can fulfil the role of representatives and all team members should take part in the monitoring process. Information should be distributed among team members and also to other teams.

The interpersonal and informational roles of the manager enable him/her to make decisions. As entrepreneur he/she indicates change by means of streamlining processes and reorganizing structures at the right time. Team members should be creative enough to do this within the team.

Crisis management is an essential part of any manager's job. Unforeseen circumstances, such as conflict among employees and strikes could arise at any time. Problems within a team should be handled by the members, but if they cannot be resolved they should be addressed at a higher level.

Managers are also responsible for the allocation of resources. They should attend to financial, human and other resource needs to ensure effective work flow. They must also facilitate internal as well as external negotiations regarding resources.

\section{Responsibilities of self-directed work teams}

Piczak and Hauser (1996:82) identify the following responsibilities of self-directed work teams. Basic responsibilities are security, user-satisfaction and in-service training; intermediate responsibilities include production maintenance, conflict resolution and scheduling of leave; and advanced responsibilities include election of team members, cost maintenance and performance evaluation. Self-directed work teams can therefore take over some management tasks and participate in decision making. These responsibilities should be allocated to teams over a period of time and initially there should be limits to what teams can do (Capozzoli 1995:19).

\section{Types of teams and the role of individual team members}

The types of teams in an enterprise are determined by circumstances. A team could be formed to perform a certain task or be formed and choose a task. Teams could work on projects for a specific time span or could exist continuously. Functional, cross-functional, managerial and employee teams are other possible types (Making teams work ... 1996:113120).

When teams were formed in the Technical Services division at Unisa's information service, there was a tendency to move away from functional divisions. However, certain functional teams were necessary. A division was made between functional teams and faculty teams. The following functional teams were formed: Ordering, Acquisitions and
Financial Administration, Serials, Bindery, Retrospective Authority Control and Database Maintenance, Indexing, and IT Support and Development. Most of these teams had existed before restructuring (as groups) and because some of these functions require specialist knowledge (e.g. the Ordering team's intimate contact with dealers) it was decided to maintain them. The Retrospective Authority Control and Database Maintenance team was project-oriented.

The five faculty teams (Economics, Management and Law; Theology and Natural Sciences; Social Sciences and Education; Cultural Studies and Languages; and Literature) were divided according to ordering codes of books, and there was also a Standards team to support them. Some functions that had previously been separated, such as preordering, physical preparation (e.g. tattletaping), cataloguing (previously descriptive and subject cataloguing) and final processing (spine marking), were combined in the faculty teams. The Standards team gave support in training (AACR2, SAMARC, etc.) and maintaining of international standards.

There were also a number of teams to address activities that were of importance to both the functional and the faculty teams, for example, the planning team, administration team and training team. These teams were the pillars on which the functional and faculty teams rested. Members of these teams are also members of the functional and the faculty teams.

The composition of a team is determined by factors such as knowledge and experience of individuals, personalities and choice. Team members must be able to work together, identify and solve problems and communicate with each other (Van Lingen 1993:7).

The above-mentioned functional teams consisted mainly of people who had done this work before restructuring but, with regard to the faculty teams, employees were encouraged to make choices. Eventually knowledge and experience and the budget allocated to order codes played a large role. Faculty teams consisted of one or two people responsible for order cards, a few cataloguers and one or two people to handle physical and final processing.

The Standards team consisted of former supervisors and, together with representatives of the functional and faculty teams, they also served on umbrella teams.

Co-operation is essential for every team. Team members share the responsibility for success as well as failure. If a faculty team, for example, have a backlog of order cards, the cataloguers should help with the cards. The non-professional people in a team could help with copy cataloguing. All team members must have a common goal. However, to White (1995:41), diversity in a team is still necessary, because it can stimulate creativity.

Self-directed teams are usually formed to create a so-called flat organizational structure and eliminate hierarchy. The necessity for a team leader or co-ordinator can therefore be questioned. In Making teams work ... (1993:24), team leaders and co-ordinators are mentioned as two building blocks of self-directed work teams. According to Andrews and Herschel (1996:82), leadership should develop informally. 
Members who are familiar with communication processes, techniques and tasks will evolve as informal leaders. In the case of the Technical Services teams, no distinction is made between team leaders and co-ordinators. The two terms are used synonymously. The term 'team leader' is not used because every team member is equal. Team members elect the co-ordinators to facilitate within the team. The coordinator is also responsible for maintaining liaison with other teams and all co-ordinators together form a management group, which consists of more people than before. This group co-ordinates collective task performance.

\section{Job enrichment and multi-skilling (versatility)}

Enterprises want their employees to be multi-skilled rather than specialists (Waterman, Waterman \& Collard 1994:88). It is easier for a versatile worker to make a career move. Barriers excluding workers from functions can be eradicated by training (Making teams work .... 1993:62).

Job enrichment is a practical way of motivating employees. It means that tasks must be reorganized to increase productivity and ensure job satisfaction for individuals. Motivation and productivity are therefore linked (Stanton 1982:23). Employees should have autonomy and control over their work. Tasks should not be fragmented and isolated but new and more complicated tasks should be added. Job enrichment and multi-skilling are also linked and, by the creation of crossfunctional teams, both can be reached.

Non-professional employees can increase their knowledge by learning the Dewey Decimal Classification system, cataloguing according to the LC subject headings and doing copy cataloguing. They are given an opportunity to be creative and make decisions. Thus, they are not just data processors anymore. Professional employees can do full book cataloguing and expand their horizons even further by taking over certain managerial tasks. To process their own team's statistics, team members have to master new software packages and creativity can be stimulated. Team members should learn each other's skills as well as the skills of other teams (Hensey 1992:69).

To be multi-skilled has certain disadvantages. Employees can become confused by too many tasks and this can have a negative impact on productivity, especially if too much is expected of employees. Therefore, training is important and should not just be focussed on teaching new tasks, but also on developing communication skills. Employees should also learn how to resolve conflict, make decisions and be responsible (Piczak \& Hauser 1996:85). It is necessary that training should be uniform. In the case of the Technical Services division of the Unisa information service, the Standards team and the Training team co-ordinate all efforts in this regard.

Teamwork skills (for co-ordinators and team members) should be taught by experts on management and business psychology (Piczak \& Hauser 1996:85). All team members must be aware of the mission of the enterprise, the structure and function of self-directed work teams, the reason why these teams have been formed and new roles and responsibilities. Training is necessary to eliminate confusion and uncertainty.

\section{Empowerment of employees}

Empowerment or the delegation of power entails that teams are equipped with formal and informal powers. Employees are able to share in problem solving and focus their energy on reaching the mission and goals of the enterprise. Employees have a bigger responsibility for their own work. According to Poon-Richards (1995:75-76), employees are empowered if they receive information about the enterprise's performance, get compensated for their contribution to that performance, have the necessary information and the ability to make that contribution and to take decisions to reach goals.

Empowerment can only be attained by those who want to be empowered (Fonda \& Rowland 1996:19). It is also necessary that the climate within the enterprise is conducive to change. In many enterprises, a hierarchic and autocratic management style still prevails despite talk about individual freedom. Employees should be recognized as the core of any enterprise, or, in the words of Gluckman (1996:12): 'our people are our main asset'. Enterprises often still feel compelled to function as parents for employees, either in a protective manner, thus compressing individuality and personal power, or in a critical manner, thus exercising strong control.

The leadership style in an enterprise has a direct influence on the empowerment of employees. Creativity and the willingness to take risks are necessary. Gluckman (1996:15) shows that only an empowered individual will be able to empower other people. This individual should know his or her strengths and weaknesses and should also be able to communicate freely. Defensiveness and aggression are not conducive to empowerment. There should be clarity of what is expected of employees and meaningful delegation should take place to ensure real empowerment. Management should not just delegate time-consuming routine tasks (Beck \& Yeager 1996:30).

It is important to ensure that employees are compensated when they attain more skills and power. Remuneration can be intrinsic (psychological) and extrinsic (economical). In nonhierarchical structures there are fewer formal promotions, because all employees are treated equally. Remuneration should be team-based, but this could be problematic in cases where some team members do not perform. Performance evaluation and remuneration on a team basis may be hampered if systems based on individual performances still exist in an enterprise (Piczak \& Hauser 1996:86).

Creativity is fostered by letting employees take their own decisions. Intrinsic remuneration includes giving interesting tasks to employees and acknowledging their achievements. Employees could be groomed for managerial positions by performing managerial tasks in teams. Employees and management will trust each other more, when they share managerial activities. Doing more difficult tasks leads to a 
motivated work force, which in turn leads to increased productivity and user satisfaction. Empowerment therefore entails that managers lead employees to perform to the best of their abilities (Poon-Richards 1995:77).

Empowerment could be reached in self-directed work teams, because employees have more responsibility for their work and they are enabled to make their own decisions. Team members are mutually responsible for the performance of a team, and job satisfaction is guaranteed by a variety of tasks.

\section{Conclusion}

Self-directed work teams focus on the employee and is therefore a form of participative management. Employees are able to take over certain managerial tasks and have more control over and responsibility for their work. Special attention should be given to the formation of teams to ensure co-operation between members and optimal performance.

Job enrichment and the opportunity to become multi-skilled can motivate employees and increase productivity, but only if the necessary training is provided. All this can lead to an empowered work force if employees want empowerment and circumstances in an information service are conducive to change. Empowerment also has advantages with regard to remuneration if the remuneration policy of an information service is adapted accordingly.

\section{References}

Andrews, P. \& Herschel, R.T. 1996. Organizational communication: empowerment in a technological society. Boston: Houghton Mifflin.

Beck, J.D.W. \& Yeager, N.M. 1996. How to prevent teams from failing. Quality progress, 29(3):27-31.

Capozzoli, T. 1995. How to succeed with self-directed work teams. Supervision, 56(8):18-19.

Curtis, D.B., Floyd, J.J. \& Winsor, J.L. 1992. Business and professional communication. New York: Harper-Collins.

Euske, N.A. \& Roberts, K.H. 1987. Evolving perspectives in organization theory: communication implications, in Handbook of organizational communication, ed. F.M. Jablin, L.L. Putnam; K.H. Roberts \& L.W. Porter. Newbury Park: Sage.
Fonda, N. \& Rowland, H. 1995. Take me to your (personnel) leader. People management, 1(23):18-23.

Gluckman, S. 1996. Looking in and looking up. People dynamics, 13(12):12-16.

Hawkins, K.W. 1989. Implementing team management in the modern library. Library administration \& management, 4(1):1115.

Hensey, M. 1992. Collective excellence: building effective teams. New York: American Society of Civil Engineers.

Hughes, B. 1994. 25 stepping stones for self-directed teams. Training, December:44-46.

Katz, M. 1993. Self-directed work teams. People dynamics, 11(9):34.

Making teams work: a guide to creating and managing teams. 1993. Burlington, Mass: Organizational Dynamics.

Martins, N. 1996. Empowerment training for coordinators. (Unpublished manual).

Osif, B. \& Harwood, R.L. 1995. Self-directed work teams. Library administration \& management, 9(2):117-121.

Piczak, M. \& Hauser, R.Z. 1996. Self-directed work teams: a guide to implementation. Quality progress, 29(5):81-87.

Poon-Richards, C. 1995. Self-managed teams for library management: increasing employee participation via empowerment. Journal of library administration, 22(1):67-84.

Saunier, A.M. \& Hawk, E.J. 1994. Realizing the potential of teams through team-based rewards. Compensation \& benefits review, 26(4):23-32.

Stanton, E.S. 1982. Reality-centred people management: key for improved productivity. New York: HMHCOM.

Successful team building: how to create teams that really work. 1992. By J. Davis, ... [et al.]. London: Kogan Page.

Van der Lingen, B. 1993. Bestuur deelnemend met selfgerigte werkspanne. Publico, 13(2):6-7.

Waterman, R.H., Waterman, J.A. \& Collard, B.A. 1994. Toward a career-resilient workforce. Harvard business review, 72(4):8795 .

White, H.S. 1995. Smearing with a broad brush. Library journal, 120(17):41-42.

Winning team plays. 1995. Supervisory management, 40(2):12-13.

Yukl, G.A. 1989. Leadership in organizations. 2nd ed. Englewood Cliffs, N.J.: Prentice Hall. 